\title{
Seblang In The Bersih Desa Tradition Of "Using” Community In Banyuwangi
}

\author{
Trisna Kumala Satya Dewi ${ }^{1}$, Heru Supriyadi ${ }^{2}$, Sholeh Dasuki ${ }^{3}$ \\ \{ ${ }^{1}$ trisna-k-s-d@fib.unair.ac.id, ${ }^{2}$ herusupriyadi@fib.unair.ac.id, ${ }^{3}$ sholehdasuki@staff.uns.ac.id $\}$ \\ ${ }^{1,2}$ Universitas Airlangga, ${ }^{3}$ Universitas Sebelas Maret
}

\begin{abstract}
In this paper, Seblang and bersih desa tradition of Bakungan are described. Seblang is a ritual dance that accompanies bersih desa(cleansing the village) tradition of Using Banyuwangi, especially in the village of Olehsari and Bakungan. The Seblang ritual in Olehsari is performed by a teenage dancer, while in Bakungan it is danced by an elderly woman who has no menstruation (menopause). Bersih desa tradition is carried out every year, which is one week after the Eid al-Fitri holiday in Olehsari village, and one week after the Eid alAdha in Bakungan Village. The Seblang ritual dance is a representation of Dewi Sri, the Goddess of Fertility in an agrarian society. The Research aim at describing and to explain the function of Seblang for society. The theory made use is function theory. The method made use is entography theory. Bersih desa is an expression of gratitude to God for all the blessings in the form of sustenance, food and clothing, safety, health, and others. This tradition can be used as a means of social bond, maintaining mutual cooperation, and preserving the environment of Using community in Bakungan, Banyuwangi.
\end{abstract}

Keywords: Seblang, bersih desa (cleansing the village), Using, Banyuwangi

\section{Introduction}

Seblang is a ritual dance that accompanies bersih desa tradition in Banyuwangi. Seblang is an agrarian culture-based ritual dance. In Banyuwangi there are two Seblang rituals, in Olehsari and Bakungan Village. Seblang dancer in the village of Olehsari are young women who are not yet mature, while in Bakungan Village the dancers are elderly (post-menopause) women. Essentially the dancer must be clean (spiritually and physically) when perform Seblang dancer. The Seblang dance is always performed in bersih desa tradition every year.In the Olehsari village is performed after the Eid al-Fitr and in the Bakungan Village, Glagah District, Banyuwangi Regency is carried out after Eid al-Adha.

The bersih desa traditions in the Bakungan village and the Seblang ritual dance are cultural treasures that are naturally owned by the Using community --- passed down by from generation to generation. Bersih desa (some people call ruwat) is a national culture, which has been preserved by the Indonesian people since ancient era. Seblang dance which is a representation of Dewi Sri (Goddess of Fertility), a myth that still lives in an agrarian society. The myth of Dewi Sri is a famous myth in Indonesia. 


\section{Research Method}

This research was conducted on the "Using" community in Bakungan Village, Glagah District, Banyuwangi Regency. The object is the Seblang dance, a ritual dance performed in a series of bersih desa traditions. The method of research is field work with a qualitative approach[1]. This research is related to the collection and recording of texts affectedby the steps that are patterned in the plan of the collectors and note takers, namely conceptions, theory, objectives, tools, settings and decisions about who should be recorded[2]. Thus, an ethnographic approach is necessary to analyze the qualitative data obtained[3], [4]. Ethnographic approach can also be assumed as a description of the way of life or culture of a society[5][6].

\section{Results And Discussion}

Bersih desa tradition asa part of collective culture passed down from generation to generation is actually a composite of ideas, values, and also human activities. Bersih desa is done once a year as a manifestation of gratitude towards Almighty God[7]. Groenendael believes that bersih desa or ruwatan is an ancestral heritage that has existed since the Old Java, in 908 AD when the reign of King Dyah Balitung in the Kingdom of Old Mataram. Bersih desa intention is to clean the village area from evil influences. In purify addition, it also strengthens bonds between citizens, invisible "watchers" or their ancestors who are trusted by their citizens to have a positive effect[8]. Bersih desa as a Javanese tradition is written in the old manuscript Serat Babad Ila-Ila[7], [9].

Bersih desa carried out by the Using community in Banyuwangi are closely related to the Seblang ritual dance. Singodimajan believes that Seblang is the oldest ritual dance in Banyuwangi. This ritual dance is inseparable from the history of the Using community which is a part of the Javanese ethnic that were isolated because of endless wars with neighboring kingdoms and Dutch companies (VOC). The Seblang dance ritual is a symbol of connecting people and their ancestors called buyut[10]. Seblang, which is the original art of the Using community, is a gift to Dewi Sri, who is a Goddess of Fertility in an agrarian society. The Seblang dancer is considered as a bead of Dewi Sri as a symbol of fertility. Seblang dance rituals that carry cosmic forces are believed to bring prosperity to the Using community[11]. Seblang dancers according to the local community will be "appointed" by the handler (pawang), village elders, and village officials. The Seblang dance, as mentioned in the previous section, in Olehsari Village is performed by a teenage girl who is not yet mature, while in Bakungan Village it is danced by an old menopause woman. This Seblang dance is then the precursor of the Banyuwangi Gandrung dance.

The Seblang dancer in Bakungan now is Mbah Supani (70 years old). She is a descendant (grandson) of Mbah Dawi, her mother is Misnah who is also a Seblang dancer. Based on the story of Mbah Supani, she is the heir to the Seblang dancer "chosen" or "got a will" from the previous Seblang dancer. Mbah Supani has been a Seblang dancer for 4 years. The handler (pawang) of Seblang in Bakungan is Pak Asri. Pawang Seblang has an important role in the implementation, both before and after the Seblang ritual. Singodimajan said that the main task of the handler is to call "ancestral spirits" when the dancer is already in the arena[10]. Mbah Supani dances with two other dancers, male and female, accompanied by 15 gendhing musicians. Bersih desa and Seblang Bakungan ritual dance were held in the morning, Sunday 
Pahing, August 25, 2019. The series of activities were carried out for three consecutive days, from Friday, August 23-25. In this event, the Bakungan people were busy preparing for the rituals as the highlight of the event. The sequences of the Seblang Bakungan ritual can be described as follows. Preparations for the Seblang arena is in front of the art studio. All activities seemed to be carried out by all members of the community in preparing for this event. Some make the stage, decorate the studio with coconut leaves, and various tuwuhan (para bungkil). Para bungkil are various kinds of vegetables such as beans, petai, mustard greens, fern leaves, and fruits such as papaya, banana, jackfruit, orange and pala kependem such as cassava, yams, and potatoes. In addition, a string of rice, corn, and coconut are also displayed in various corners of the village that resemble a small shop - all harvest of Bakungan people.

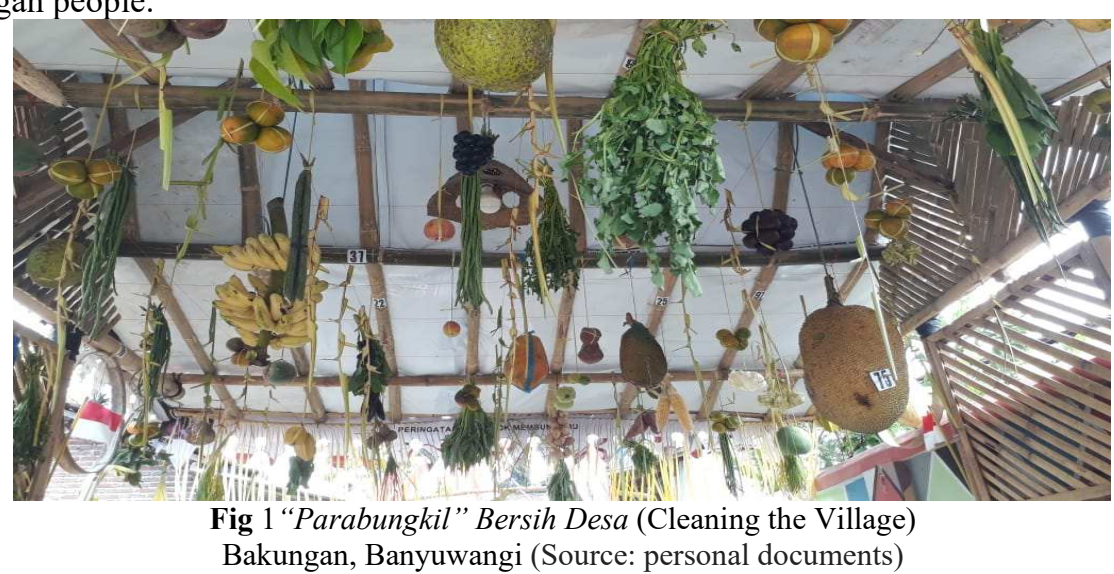

Villagers prepare pecelpitik rice cone (tumpeng), a whole chicken which is seared and then cooked. In 2019, the Bakungan community prepared 3000 steamed chicken (ingkung) to make pecelpitik cuisine which was provided by each head of the family. In front of their houses, the residents had started to cook 2 or 3 steamed chicken. One resident said that pecelpitik will later be eaten by all members of his family and guests in Bakungan Village after the salvation prayer (Interview with Mr. Sugito, 67 years old, village elder, on Sunday, August 25, 2019).

Preparation for the Seblang ritual performance begins at noon around 14.00 WIB. First a pilgrimage or nyekar to the tomb of BuyutFitri, a Seblang dancer. After that the journey continues to fetch water from SumberPenawar in WatuUla, Bakungan Village. Water from the well is believed to be efficacious as a treatment.

In the evening, exactly after the evening prayers,iderbumi is carried out. Iderbumi is trip of religious leaders, and residents starting from the front of the mosque around the village with a torch (oncor) for about 30 minutes in complete darkness, the electric lights are turned off. The torch is also placed on several village roads and in front of the art studio where the stage of Seblang is located. After the procession was finished, a group prayer was led by one of the ulemas, who pray the grateful to God for the abundance of blessings in the form of sustenance and asking for salvation for all Bakungan residents.

Bersih desa traditions is accompanied by slametan (prayer) with pecel pithik. The residents and the guests enjoyed the rice cone pecel pitik. The people's party in the village of Bakungan is held by its citizens with joy. Pecel pitik is also served in other traditional events. The basic ingredient of this food is chicken (about 8 months old) - this chicken is grilled in a fireplace. After that it is served with grated green coconut mixed with mashed beans. The roasted beans are mixed with spices, spicy seasonings' and stirred evenly with coconut water until the spices 
are absorbed and mixed with chicken that has been cut into several parts[12]. The Seblang ritual, both in the village of Olehsari and Bakungan cannot innovate like other traditional arts. The ritual sequences are strongly obeyed by the people[13].

Seblang performances can be explained as follows. First, the Seblang dancer entered the stage area. Seblang Bakungan is a tradition that has been going on since 1639. Seblang is a form of gratitude for the abundance of crops. In addition, it is a wishingfor the abundant harvests and avoid all kinds of disasters, diseases, and pests. Second, Seblang Lokento; the night performance beginwith the chanting of the song Seblang Lokento. Chanting as a tribute to the ancestors attempt inviting the ancestors to the arena. Third, Padha Nonton, an invitation to watch or witness the

Seblang ritual. Padha Nonton is a form of tribute to the audience who watch the Seblang ritual. Moreover, it honor the struggle of the ancestors who sacrificed for the glory of Bumi Blambangan and Indonesia. Padha Nonton is also an invitation and message of the struggle of the people of Banyuwangi to continue to strive to achieve mutual prosperity[13].

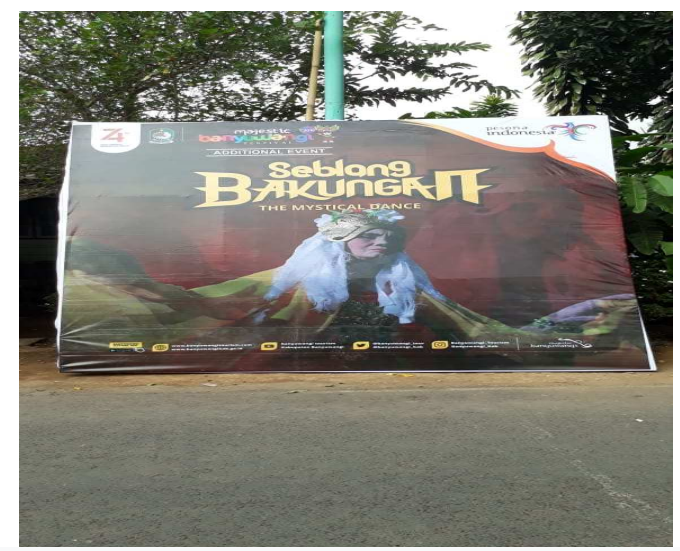

Fig 2. Seblang dancers, Bakungan, Banyuwangi (Source: personal documents)

Omprog is a special crown worn by Seblang dancers. During the ceremony, the omprog look sacred with the decoration of colorful fresh flower and leaves. Omprog has a philosophical meaning as the incarnation of Dewi Sri[10].

The tradition in Bakungan Village is carried out to praise God Almighty for abundant blessings, to preserve traditions, and to strengthen harmony of the community. This is in line with the information from Mr. Fathur Rofik, Head of Bakungan Village, Ms. Yuliati, Chairperson of the PKK Team, and Mr. Jumanto, Chairperson of Seblang Bakungan. Seblang tradition is an art of peace in the Using community, Banyuwangi.

\section{Conclusion}

Seblang is a ritual dance that accompanies the bersih desa tradition functioning as a binder of peace, forming brotherhood, and welfare of the Using Banyuwangi community. Seblang dance and gendhing movements in the form of wangsalan can be used as a pillar of cultural resilience because of the nuances of struggle and the spirit of the Using Banyuwangi community. Bersih desa tradition of the Using Banyuwangi community is full of local 
wisdom, which is respecting "food" is an expression of gratitude for the harvest of the Using community. Tetuwuhan called para bungkil is a symbol of tetanen (agriculture) in an agrarian society. Bakungan's cleansing village which is an expression of gratitude to God can be used as a social bond for the community, foster mutual cooperation, and preserve the environment.

\section{Acknowledgments}

This article is part of a study entitled "The Agricultural Myth of Dewi Sri: The Retention and Development Models of Performing Arts Traditions as Social Bonding in Java-Madura". DRPM of Ministry of Research, Technology, and Higher Educationis highly appreciated for funding the research.

\section{References}

[1] J. Danandjaja, Folklor Indonesia: Ilmu Gosip, Dongeng, dan Lain-lain. Jakarta: Grafiti Press, 1986.

[2] R. Finnegan, Oral Poetry, Folklore, Cultural, Performances, and Populer Entertaiments. New York: Oxford University Press, 1992.

[3] A. Sutarto, Legenda Kasada dan Karo Orang Tengger Lumajang. Jakarta: Fakultas Sastra Universitas Indonesia, 1997.

[4] E. all. Trisna Kumala Satya Dewi, "Mitos Pertanian Dewi Sri: Model Pemertahanan dan Pengembangan Seni Pertunjukan Tradisi sebagai Perekat Sosial Masyarakat di Jawa-Madura," Surabaya, 2019.

[5] G. D. Berreman, "Ethnography: Method and Product," in Introduction to Cultural Antropology, J. A. Clifton, Ed. Hougthon: Miffin Company.

[6] K. Saddhono, "Integrating Culture in Indonesian Language Learning for Foreign Speakers at Indonesian Universities," J. Lang. Lit., vol. 6, no. 2, pp. 349-353, 2015.

[7] T. K. S. Dewi, "Transformasi Mitos Dewi Sri dalam Masyarakat Jawa," Universitas Indonesia, 2009.

[8] C. van Groenendael, Dalang di Balik Wayang. Jakarta: Pustaka Utama Grafiti.

[9] M. Sastronaryatmo, Babad Ila-Ila Jilid I. Jakarta.

[10] H. Singodimajan, Ritual Adat Seblang: Sebuah Seni Perdamaian Masyarakat Using Banyuwangi. Banyuwangi: Dinas Kebudayaan dan Pariwisata Kabupaten Banyuwangi, 2009.

[11] N. Anoegrajekti, "Gandrung Demi Hidup Menyisir Malam,” Srinthil, 2003.

[12] N. Rohmawati, "Konsumsi Makanan, Kuliner, dan Obat-obatan Masyarakat Using Banyuwangi,"” in Kebudayaan Using: Konstruksi, Identitas, dan Pengembangannya, Yogyakarta: Ombak, 2016.

[13] N. Anoegrajekti et al., Potensi Budaya Using dan Industri Kreatif. Jember: Lembaga Penelitian dan Pengabdian kepaekerja sama dengan Penerbit Ombakda Masyarakat Universitas Jember b, 2018. 